\title{
IS THERE ANY RELATIONSHIP BETWEEN THE RIGHT OF WITHDRAWAL FROM THE EU AND EUROPEAN IDENTITY? THE BREXIT CASE
}

\section{Özlem SEFER ${ }^{1}$}

\begin{abstract}
One of the main regulations made in the Treaty of Lisbon is Article 50, which brought the right of withdrawal from the European Union (EU) to the member states. In the referendum that was held in the UK in 2016, the UK citizens voted to leave the Union and the UK became the first country that preferred to withdraw from the EU. The construction of European identity in the EU has been one of the most significant issues related to legal regulations at the EU level. This article will examine the concept of identity in the EU, the role of the legal regulations in the EU in the construction of European identity, and the relationship between the right of withdrawal and identity in the EU by analyzing the Brexit case.
\end{abstract}

Keywords: European Identity, The Right of Withdrawal from the EU, Brexit.

Jel Classification: F5, K39, D72

\section{AVRUPA BİRLIĞǴ'NDEN ÇIKMA HAKKI VE AVRUPA KİMLİĞí ARASINDA BİR BAĞLANTI VAR MIDIR? BREXIT ÖRNEĞİ}

\author{
$\ddot{O} \mathbf{z}$
}

Lizbon Antlaşması'nda yapılan en temel düzenlemelerden biri, üye ülkelere Avrupa Birliği’nden (AB) çıkma hakkı getiren 50.maddedir. 2016 senesinde Birleşik Krallık’ta yapılan referandumda, Birleşik Krallık vatandaşları Birlik’ten ayrılmak yönünde oy kullanmış ve Birleşik Krallık AB'den ayrılmayı tercih eden ilk ülke olmuştur. AB'de ortak bir kimlik oluşturulması en önemli meselelerden biri olup, AB düzeyindeki hukuki düzenlemelerle de bağlantılıdır. Makalede, AB'de kimlik kavramı, AB'deki hukuki düzenlemelerin Avrupa kimliği oluşturmaktaki rolü ve çıkma hakkıyla AB'deki kimlik konusu arasındaki ilişki Brexit örneği göz önüne alınarak incelenecektir.

Anahtar Kelimeler: Avrupa Kimliği, AB’den Çıkma Hakkı, Brexit.

Jel Sinıflaması: F5, K39, D72

\footnotetext{
${ }^{1}$ Ph.D., Bilkent University, Department of Political Science and Public Administration, Part-time instructor, ozlem.sefer@bilkent.edu.tr, ORCID: 0000-0002-7730-6556
} 


\section{Introduction}

European integration, with its multiple dimensions, is a long-term and challenging process. Any change or innovation in one of these dimensions, such as the legal regulations, affects the other dimensions directly or indirectly. From the Treaty of Paris (1951), until now, twenty-eight countries have become the members of the European Union (EU) -but after Brexit the number of the countries changed and became twenty-seven- and all of the regulations were made through the accession and harmonization processes of the Union. Until 2009, when a country became a member of the Union, it was not possible to withdraw from this partnership; "Indeed, prior to the Lisbon Treaty, there was no Treaty article dealing with the possibility that a state might wish to leave" (Craig, 2017, p.31). The new right under the title of "voluntary withdrawal from the Union' is in Article 50 and it was granted to the EU member states by the ratification of the Treaty of Lisbon.

Article 50 affects multiple facets of EU politics and economics such as implementation of common policies and EU citizenship regulations. One of these facets is the common identity among the EU citizens, which would be affected by this withdrawal, not only legally but also socially and politically. When considering the efforts of creating 'we-ness' and 'commonalities' at the EU level, there is an implicit relationship between European identity and the right of withdrawal. In the EU integration process, the effect and the role of identity issues in the EU cannot be ignored. This paper will focus on the right of withdrawal from the European Union and its relationship with the identity issue in the framework of the Brexit case. The interaction between the sense of belonging to the EU and the exit option for the EU member states will be argued. When Article 50 made 'exit option' possible, this would be a kind of 'exam' for European identity as well. The common identity among European citizens will be analyzed as a sui generis identity whose components are affected from the legal regulations in the EU level. The efforts of the construction of European identity for the Union are not new. The EU has long suffered from identity debates. However, especially after the 'birth' of the right of withdrawal in the EU law, this right compels the rethinking of the identity issue again in the framework of the potential demands of the member countries to leave the Union. Brexit, as one of the main contemporary and debatable issues in the EU agenda, will be examined as a case to examine the relationship between the right of withdrawal and the feeling of attachment of the EU citizens towards the EU. In the first part of the article, European identity will be discussed by focusing on the essentialist and constructivist approaches and it will be analyzed as an identity that can be constructed via economic, political and legal regulations. In the last part, as one of the main concepts of this paper, Article 50 will be examined by considering the paragraphs to understand the concept and to anticipate the process of withdrawal most correctly and the relationship between the right of withdrawal and European identity will be discussed in the framework of the Brexit case.

\section{European Identity for the EU Citizens: What kind of identity?}

European identity is commonly used in different contexts and with several meanings in the EU literature. It can be found, directly or indirectly, in many situations in the law, economics and politics of the EU. Especially, after the transition from permissive consensus to active participation of the EU citizens, its role has started to be visible in the EU decision-making process. 
In other words, in the 1990's it was realized that the EU cannot sustain the EU project with permissive consensus (Eising, 2019, p.206) and it should be more than a technocratic project. The Union has deepened and widened over time so 'unity in diversity' has started to increase and the integration of citizens to the EU has become one of the most salient issues.

"Is European identity something unrealistic or impossible to think of?" (Cerutti, 2001, p.3). Of course not; it is possible to think of identity beyond the nation-state. "European identity is not a given, nor does it fall from heaven: it is a specific construct in time and space whose content actually changes depending on the social and political context in which it is enacted" (Risse, 2009, p.156). Because of its sui generis structure, it is difficult to anticipate the features of a common identity of the EU because the identity for the EU citizens couldn't be compared with any other type of identity. One of the criticisms on the absence of a European identity is on the lack of a 'European society' instead of European societies. However, this situation does not affect the construction of an identity for the EU negatively. It is possible to mention the integration of European societies to the EU. Using other terminology, for the EU, instead of demos, it can be mentioned demoi (Weiler, 1998, p.32). The EU has several national demoi and this shows the heterogeneous and plural quality of the Union (Baykal, 2005, p.51).

To construct a sense of belonging, an identity for the EU citizens is essential. In this sense, the potential elements to create a common identity among European citizens have been a contentious issue. Is it possible to use cultural elements such as traditions, customs or any other cultural aspect to create a common identity at the EU level? Or is it necessary to construct economic, political and legal frameworks to supply the sense of 'we-ness'? The construction of identity in the EU should be different from nation-states' or, in other words, it should be different from national identity. It should be noted that the aim of the construction of European identity is not to create a substitute for national identities. "In other words, the European polity does not require a 'demos' that replaces a national identity with a European identity, but one in which national and European identities coexist and complement each other" (Risse, 2009, p.152). European societies have different cultural features and backgrounds so the emphasis on the specific cultural elements might stay at national level. Language, religion, tradition and customs as the concepts of culture are highlighted by essentialism (Ifversen, 2002, p.6). According to the essentialist view, common culture is a precondition to create a common identity, but it seems not possible for a multicultural sui generis Union given that “...essentialist identity, based on cultural and ethnic features, and constructive identity, founded on political, symbolic and social elements" (Scalise, 2015, p.595). Cultural similarity is not a precondition or an obligation for the construction of a common identity in the EU. A 'we-feeling' can be constructed without common elements such as culture but by supplying participation of the citizens to create a common identity as political construction (Schmidt, 2011, p.18). According to McCormick's definition “.... European is someone who is a citizen of a European state and self-identifies as European in addition to, or in place of, their legal status as a citizen of their home state" (McCormick, 2016, p.100). Therefore, defining 'European' does not distance itself from the EU law and even these terms are directly related with each other.

According to Article 2 of Treaty on European Union:

"The Union is founded on the values of respect for human dignity, freedom, democracy, equality, the rule of law and respect for human rights, including the rights of persons belonging to minorities. 
These values are common to the Member States in a society in which pluralism, nondiscrimination, tolerance, justice, solidarity and equality between women and men prevail" (Consolidated Version of the Treaty on European Union, 2012).

The values that are determined in Article 2 of the Treaty on European Union do not have emphasis on any cultural value of any member state. The member states should adapt their legal, political and social order by considering values such as democracy, equality, justice etc. to be a part of the EU. Therefore, the countries that would like to be a part of the Union can construct these values by the harmonization of their economic, legal and political spheres.

It is not facile, straightforward work to separate the cultural, political and legal elements of identity completely, but in the EU's case, different regulations exist such as EU citizens' rights to construct an identity beyond nation-states. EU citizenship is one of the main granted rights in the deepening process and one of the main components of the European identity. By the ratification of the Treaty on European Union, EU citizenship ascended on the stage and this is one of the most significant steps for the proximity of European societies. “...regardless of race, ethnicity, language, religion or culture, anyone who accepts the rules and values of the EU can be an EU citizen" (Fligstein et al., 2012, p.117). The EU citizens have rights such as: right to move and reside within the EU; right to vote and be a candidate in elections of the European Parliament and municipal elections; the consular protection in any Member state like the national citizen of that state; right to apply to the European Ombudsman and petition to the European Parliament (Consolidated Version of the Treaty on the Functioning of the European Union, 2012). By building up a 'we-feeling' with the help of the commonalities in legal areas at the EU level, the road for the construction of a European identity could be opened. As mentioned previously, finding a common cultural background seems quite challenging for the $\mathrm{EU}$, so in this article European identity refers to an identity, which is affected by common legal rules and implementations. In this context, the implementation of the acquis communautaire also affects the identity issue. There are several regulations at the EU level from which some countries are exempt that are known as opt-outs and these exemptions might affect the 'wefeeling' in a negative way. For example, the UK is one of the countries that has opt-outs and the UK is the first country that would prefer to leave the Union. Therefore, it seems meaningful to focus on the relationship between implementation of the EU law and the right of withdrawal. The implementation of the EU law in all EU countries similarly may help to increase the level of sense of belonging to the EU and to the construction of a European identity. The EU citizens who have a sense of belonging to the Union do not prefer to leave this 'partnership' and they would prefer to stay as a part of this 'group'. All of the social identities might be together without any conflict (Risse, 2010, p.23). "There is social identity on the national level, for instance a German or Italian European, and there is social identity on the inclusive level, that is a German or Italian European" (Mummendey \& Waldzus, 2004, p.60).

Being a part of a 'group' brings the sense of belonging to that group so it also affects the identity issue. While defining 'we' and 'others', the borders are created and these borders can be named as soft borders that people draw between each other (Eder, 2006, p.255). The meaning of border can be analyzed under two headings: hard borders and soft borders. The passport as an identity card might be an example of hard-border that separates citizens and non-citizens. (Delanty, 2006, p.189) The hard borders are tangible, and with certain rules and regulations it is possible to pass them. 
However, to pass soft borders, sometimes rules and regulations are not enough, 'consent' and 'approval' of the 'group-members' are essential. "Borders thus have a symbolic role in marking the boundaries of the "we group" (Delanty, 2006, p.187). Therefore, is it possible to refer to an interaction between hard borders and soft borders? The Schengen Agreement specifies hard borders of the EU and the EU citizens have started to use a common visa, except some countries that have opt-out, such as the United Kingdom. However, it should be noted that the UK has opt-in for some parts of Schengen (European Parliament Fact Sheets on the European Union, 2019). According to Delanty: “...the Schengen countries have more open borders than those that are not within this agreement" (Delanty, 2006, p.189). This 'openness' can be interpreted by considering not only hard borders but also soft borders. The main importance of soft borders is its relationship with the identity issue in the EU. When the EU citizens experience the free movement of goods, capital, services and labour and the common currency and visa, they might feel the integration process of the EU and might feel closer to the other EU citizens (Bergbauer, 2018, p.31). Therefore, besides hard borders, the Schengen Agreement created soft borders of the Union. If any country is out of these borders permanently or, in other terms, has opt-out in common areas, it makes it difficult to construct a common identity in the EU and to supply the feeling of 'Europeanness'. This might affect the construction of the identity for the EU citizens in a negative way because of the lack of the implementation of common rules and regulations in each member state of the Union.

According to the results of the EU Citizenship Report in 2020, the most cherished right by the EU citizens is freedom of movement (EU Citizenship Report 2020 Factsheet, 2020). People who lived in the member states that were in 'euro-area' saw themselves as European citizens more than as non-euro member states' citizens (Standard Eurobarometer 89 European Citizenship, Spring 2018). In the 2020 Standard Eurobarometer, $79 \%$ of the EU citizens in the euro area support euro (Standard Eurobarometer 94, Winter 2020-2021). It should be noted that in utilitarian approach, people's attitudes might be shaped in the framework of cost-benefit analysis (Hobolt \& Wratil, 2015, p.239). The benefits of freedom of movement, common currency and other regulations cannot be underestimated, but these symbols might be conducive to increase the perception of common identity among European citizens. These symbols are the products of the legal regulations in the EU level and can be used to construct common identity among the EU citizens.

\section{Article 50 and the Brexit case}

Until the ratification of the Treaty of Lisbon, there were no regulations about withdrawal but only about suspension. Suspension is the competence of the EU so this is a kind of sanction for a member state. In Article 7 of the Treaty on European Union, the suspension rule was adopted (Consolidated Version of the Treaty on European Union, 2012). The suspension rule may help to protect the core values, economic and political stability of the EU as an institution. By the help of the suspension rule, the EU can protect the interests of the member states and its own principles. However, there wasn't any option to exit for the member states when they faced any undesired circumstances until the ratification of the Treaty of Lisbon. It can be said that the suspension rule exists for protecting the EU values and interests and the right of withdrawal exists to allow a member state to make a choice to be or not to be in the EU.

Although there had not been any instances of withdrawal from the Union before the ratification of the Treaty of Lisbon, Greenland has been perceived as a withdrawn state. 
The overseas territories of any country could not participate in the Union as a member state just because they are in the Union as parts of that member state. Greenland is such an example. The Treaty establishing the European Economic Community, part four, included the Association of the Overseas Countries and Territories. In this part in Article 131, it stated: "The Member States hereby agree to bring into association with the Community the non-European countries and territories which have special relations with Belgium, France, Italy and the Netherlands" (Treaty establishing the European Economic Community, 1957). By the enlargement waves, the number of countries and their overseas territories increased and with the membership of Denmark in 1973, the overseas territory of Denmark, Greenland, became one of these territories. According to this Treaty's related article, Greenland joined European Economic Community (EEC) automatically not as a member state but as an overseas territory. After its separation from Denmark, in 1982, Greenland held a referendum and, as a result, the country decided not to participate in the EEC. "Having been a part of the European Community since 1973 through Denmark's membership, Greenland withdrew from the European Community in 1985 after the island secured Home Rule from Denmark" (Bentzen \& D'Alfonso, 2019). Greenland's case is not associated with withdrawal from the EU because of its special status. Therefore, it is not possible to refer to any withdrawal from the EU until the Treaty of Lisbon. The Constitutional Treaty (not ratified) provided for an 'exit' from the EU with Article 59, which allows for the voluntary withdrawal from the Union. Its successor, the Treaty of Lisbon, includes both suspension and withdrawal provisions.

According to the right of withdrawal, any EU member state can decide to withdraw from the EU. In the first paragraph, Article 50(1), the main sentence on withdrawal can be found (Consolidated Version of the Treaty on European Union, 2012). To start the withdrawal process, the member state should inform the European Council firstly as arranged in Article 50(2) (Morphet, 2017, p.16). When a state would like to leave the Union, a qualified majority is necessary in the Council. However, the member states do not have any veto power not only about the process but also about the conclusion (Peers \& Harvey, 2017, p.827). In this paragraph, one of the main significant points is the 'arrangements by taking account of the framework for its future relationship with the Union' (Consolidated Version of the Treaty on European Union, 2012) in which the withdrawn state could sustain its relations with the Union. However, it seems not possible to foresee the specific features of any potential relations because of the open-ended structure of this paragraph. There might be partnership agreements the same as in the countries that are not a member but have relationships with the Union. Another scenario is the withdrawn state may become any other state that is out of the Union, which means that there would not be any economic and political relations with the EU.

As it was specified in Article 50(3), the withdrawal is a 'process' (Consolidated Version of the Treaty on European Union, 2012). When a member state applies for withdrawal from the Union, it is necessary to wait for two years until the procedure is completed: "Before withdrawal eventually becomes effective, either the two-year period must have expired or a withdrawal agreement must have been successfully concluded" (Hofmeister, 2010, p.593). If there is no agreement in the European Council about the withdrawal of that state, the period might be longer than two years (Consolidated Version of the Treaty on European Union, 2012). As it was experienced in the Brexit case, the withdrawal process has taken more than two years. The date 23 June 2016 is one of the remarkable dates in the United Kingdom (UK) and in the history of the EU. In the UK, a referendum was held to leave or remain in the EU as a member state. 
The result showed that the majority of the UK citizens voted for 'Leave'. The UK is the first country that would prefer to be out of the Union. The implementation of Article 50 has been observed within a period referred to as 'Brexit'. On $31^{\text {st }}$ January 2020, the UK withdrew from the EU and the transition period started. After the transition period, the withdrawal process completed and the UK was separated from the EU officially. The referendum results revealed that the UK citizens prefer to leave the EU. In fact, $51.9 \%$ of British citizens would prefer to be out of the Union (BBC News, n.d.). The results in England, Wales, Scotland and Northern Ireland were different from each other. In England and Wales, the percentage to leave the EU is $53 \%$ but in Northern Ireland $56 \%$ and in Scotland $62 \%$ of people preferred to remain as a part of the EU (Hobolt, 2016, p.1273). In the period of the referendum campaign, it was seen that the 'Leave' side and the 'Remain' side had different arguments. The fear of losing national identity and immigration were the main issues for Brexit (Hobolt, 2016, p.1273). Regaining the sovereignty of the UK is like a motto of the 'Leave' campaign (Glencross, 2016, p.69). "The messages were clear: vote 'Remain' to avoid the economic risk of a Brexit ('A leap in the dark') or vote 'Leave' to regain control of British borders and British law-making and to restrict immigration ('Take back control')" (Hobolt, 2016, p.1262). The salience of sovereignty and economic issues for the UK cannot be ignored but the identity issue that is related to migration and the integration to the EU is significant as well (Hobolt, 2016, p.1271). The construction of identity has been one of the controversial issues in the EU but it would be misinterpretation to examine the identity issue in the UK without emphasizing the Eurosceptic perspective of the country. In the UK case, Euroscepticism should be taken into account while interpreting referendum results. The British public has been known as Eurosceptic and the number of exit sceptics could not be underestimated before the referendum as well (De Vries, 2018, p.155). As it was mentioned earlier, opt-outs of the UK might indicate the relationship between the implementation of the common legal regulations in the EU level and European identity. According to the results of a Eurobarometer survey on European Citizenship, a few months before the Brexit referendum, in the UK, $62 \%$ of the citizens defined themselves with their 'nationality only' and $31 \%$ of them defined themselves with their nationality firstly and then with Europe (Standard Eurobarometer 85 European Citizenship, Spring 2016). The survey results showed that $3 \%$ of them felt European in the first place and then they defined themselves with their nationality, and $1 \%$ of them said that they felt European only (Standard Eurobarometer 85 European Citizenship, Spring 2016).

If a member state withdraws from the Union, it will not be possible to be represented in the European Council anymore as specified in Article 50(4) (Consolidated Version of the Treaty on European Union, 2012). In the fourth paragraph, it was mentioned, 'qualified majority voting' so it should be noted that the voting style changed with the Treaty of Lisbon and named as 'double majority'. The increasing role of the EU citizens in EU politics is exactly one of the main targets for the functioning of the Union. The 'voice' of citizens is significant in the decision-making process. Being a part of a group -EU- means one more identity for the European citizens and this new identity brings loyalty. In his famous book, Hirschman focused on the relationship among exit, voice and loyalty and he pointed out: "The reluctance to exit in spite of disagreement with the organization of which one is a member is the hallmark of loyalist behaviour" (Hirschman, 1970, p. 98). He added that if there is a belief among the customers about the possibility of change, they raise their voice and try to change the problematic issue instead of exit (Hirschman, 1970, p.37). 
Therefore, if a person does not want to detach from his/her identity, he/she might use the 'voice' option by being a part of the process to change the conditions. In the EU case, if the EU citizens are interested in the EU issues and feel as 'Europeans', they do not want to give up their European identity and their citizenship of the EU as a legal status so they prefer to stay as a part of the Union. Citizens would like to be more interested in the 'issues related with the EU' if they are convinced that the EU can hear their 'voice'. As Schmidt emphasized, identity is related not only with 'being' but also with 'doing' and 'saying' (Schmidt, 2011, p.18). If there are problems in terms of the functioning of the EU politics, the EU citizens have channels such as the European Parliament and the European Citizens Initiative to raise their 'voice' to change problematic and undesired issues at the EU level. However, if there is a lack of interest of the citizens in EU politics and there is an absence of common identity, the selection of 'exit' option might be on the stage.

The 'rejoining' paragraph is the fifth paragraph in the Treaty and when the withdrawn state wants to rejoin, it is necessary to follow the same path. It can be said that this paragraph leaves the 'door halfway open' to the withdrawn state to be a part of the Union again but there is no guarantee.

To be a member of the Union, all member states should meet specific criteria and align with the EU law. It means that if a country decides to withdraw from the Union, it is crucial to make a new economic and political plan but this process would not be effortless. By the Customs Union, member states specified common tariffs; by the Schengen agreement, they started to use a common visa; by creating the Eurozone, they started to use the same currency and with any other common policies there have been cooperation in many areas. After the withdrawal, all of these common areas might be abolished or rearranged so it would also affect the daily lives of the withdrawn state's citizens.

There is a correlation between the right of withdrawal and identity issue so the right of withdrawal has meaning beyond its legal dimension and it would show the potential of the internalization of the common European identity by the EU citizens. Therefore, Article 50 of the Treaty of Lisbon might show the level of integration of the EU citizens to the EU by considering the choice of the citizens in terms of leaving or staying as a part of the EU. The Union's structure does not resemble any other organization. Because of its 'uniqueness', it is not easy to mention a specific 'formula' to construct an identity among EU citizens. If the EU citizens feel 'European', have a sense of belonging to the EU, it might affect the potential referendum results in the future so the right of withdrawal might just stay as a 'right'. As mentioned earlier, if there is a sense of belonging, it is not easy to renounce one's European identity.

To sum up, the right of withdrawal and identity issues are related to each other. If there is a legal regulation on exit such as Article 50, the attitudes of the citizens towards the EU are salient and significant. If there is a strong sense of belonging and common European identity among the EU citizens, the 'exit option' would not be an attractive option. For the EU citizens. The meaning of the demand of withdrawal of any member state not only shows the application of this new rule in practice but also the level of integration of the EU citizens to the EU. It can be said that the desire of withdrawal of any member state not only affects the economic and political aspects but also the legal and social aspects of the Union. For instance, the citizenship status of the EU citizens will be over. Henceforth, the EU citizens will lose their right of free movement and they cannot reach the common market of the EU (Closa, 2017, pp.517-518). 
These issues are directly related with the legal regulations of the EU and it seems impossible to ignore the effects of these rights from the social perspective.

\section{Conclusion}

Article 50 of the Treaty of Lisbon affects the EU as a whole. The desire for withdrawal of the member state is related not only with the economics and politics but also the sense of belonging of the EU citizens to the Union. Any regulations or amendments in the EU law affect the lives of the EU citizens and also the identity issue in the EU. The implementation of Article 50 has been observed with the withdrawal of the UK. The withdrawal is a process, so the future relations between the UK and the EU have just started to be clear. When a member state decides to withdraw from the EU, the conditions of partnership and future relations with the EU will be observed by considering the Brexit case.

If the EU citizens feel 'European' by the help of the legal instruments then they would not want to lose their EU citizenship and identity, which may mean that a large extent of the support of the EU citizens for the withdrawal from the EU will decrease in the future and the public support affects the EU integration process in a positive way. If the EU citizens have a strong European identity and they believe that being an EU member is more advantageous than withdrawal, they would not have any idea or intent to leave the Union.

Brexit, as a case, might be related with any economic, political, legal problems within the EU but its relevance to European identity issue cannot be underestimated. If there is a strong sense of belonging to the EU, the citizens of the EU would prefer not to vote for the withdrawal from the Union. If the feeling of attachment can be constructed effectively, EU citizens do not want to give up their EU citizenship as a legal status and their European identity as one of their social identities. This construction is a two-way process; EU citizens should be enthusiastic to internalize European identity and the EU should support EU citizens by using instruments at the EU level. Brexit is a 'signal' about the sense of belonging to the EU and indicates the significance of the construction of identity in the EU. However, it should be noted that the identity construction process is a mutual process so both the EU citizens and the EU should make an effort. It is hard to say that the withdrawal of a member state is purely related with the identity issue in the EU while examining other approaches such as the utilitarian approach but if there is a strong sense of belonging to any group, detaching from that identity couldn't be so easy. Therefore, the identity construction efforts in the EU are so meaningful for the integration of the EU citizens to the EU. If the process of identity construction is managed successfully, the number of member states might change in the Union because of new enlargement waves, not because of withdrawals, and the EU will herald in effective integration, not disintegration.

\section{References}

Baykal, S. (2005). Unity in Diversity? The Challenge of Diversity for the European Political Identity, Legitimacy and Democratic Governance: Turkey's EU Membership as the Ultimate Test Case. Jean Monnet Working Paper, 09 (05), 1-78. 
Bentzen, N. \& A. D’Alfonso, A. (2019, April) EU Cooperation with Greenland. European Parliament. https://www.europarl.europa.eu/RegData/etudes/BRIE/2019/637922/EPRS_BRI(201 9)637922_EN.pdf

Bergbauer, S. (2018). Explaining European Identity Formation: Citizens' Attachment from Maastricht Treaty to Crisis. Springer.

Cerutti, F. (2001). Towards the Political Identity of the Europeans: An Introduction. In F. Cerutti,\& E. Rudolph (Eds.), A Soul For Europe: Vol.1 A Reader (pp. 1-31). Va.: Peeters.

Closa, C. (2017). Changing EU internal borders through democratic means. Journal of European Integration, 39 (5), 515-528.

Consolidated Version of the Treaty on European Union, 2012, https://eurlex.europa.eu/resource.html?uri=cellar:2bf140bf-a3f8-4ab2-b506fd71826e6da6.0023.02/DOC 1\&format=PDF

Consolidated Version of the Treaty On The Functioning Of The European Union, 2012, https://eur-lex.europa.eu/legalcontent/EN/TXT/PDF/?uri=CELEX:12012E/TXT\&from=EN

Craig, P. (2017). Development of the EU. In C. Barnard \& S. Peers (Eds.), European Union Law (pp. 9-36). Oxford University Press.

De Vries, C.E. (2018). Euroscepticism and the Future of European Integration. Oxford University Press.

Delanty, G. (2006). Borders in a Changing Europe: Dynamics of Openness and Closure. Comparative European Politics, 4, 183-202.

Eder, K. (2006). Europe's Borders: The Narrative Construction of the Boundaries of Europe. European Journal of Social Theory, 9 (2), 255-271.

Eising, R. (2019). Interest Groups and the European Union. In M. Cini \& N. Perez-Solorzano Borragan (Eds.), European Union Politics (pp. 201-218). Oxford University Press.

EU Citizenship Report 2020 Factsheet. (2020, December 15). Retrieved June 23, 2021, from https://ec.europa.eu/info/sites/default/files/eu_citizenship_report_2020_-

factsheet_en.pdf

EU Referendum $\quad$ Results. (n.d.). $B B C \quad$ News. https://www.bbc.com/news/politics/eu_referendum/results

Fligstein, N., Polyakova, A. \& Sandholtz, W. (2012). European Integration, Nationalism and European Identity. Journal of Common Market Studies, 50 (S1), 106-122.

Free movement of Persons. (2019). European Parliament Fact Sheets on the European Union. Retrieved March 29, 2019, from http://www.europarl.europa.eu/factsheets/en/sheet/147/free-movement-of-persons

Glencross, A. (2016). Why the UK voted for Brexit: David Cameron's Great Miscalculation. Palgrave Macmillan.

Hirschman, A.O. (1970). Exit, Voice and Loyalty: Responses to Decline in Firms, Organizations and State. Harvard University Press Cambridge.

Hobolt, S.B. \& Wratil, C. (2015). Public Opinion and the crisis: the dynamics of the support for the euro. Journal of European Public Policy, 22 (2), 238-256.

Hobolt, S.B. (2016). The Brexit vote: a divided nation, a divided continent. Journal of European Public Policy, 23 (9), 1259-1277.

Hofmeister, H. (2010). 'Should I Stay or Should I Go?'- A Critical Analysis of the Right to Withdraw from the EU. European Law Journal, 16 (5), 589-603.

Ifversen, J. (2002). Europe and European Culture- A Conceptual Analysis. European Societies, $4(1), 1-26$. 
McCormick, J. (2016). Why Europe Matters for Britain: The Case for Remaining In. Palgrave Macmillan.

Morphet, J. (2017). Beyond Brexit? How to assess the UK's future. Policy Press.

Mummendey, A. \& Waldzus, S. (2004). National Differences and European Plurality: Discrimination or Tolerance between European Countries. In R.K. Herrmann, T. Risse \& M.B. Brewer (Eds.), Transnational Identities: Becoming European in the EU (pp. 59-72). Rowman \& Littlefield Publishers.

Peers, S. \& Harvey, D. (2017). Brexit: The Legal Dimension. In C. Barnard \& S.Peers (Eds.), European Union Law (pp. 815-836). Oxford University Press.

Risse, T. (2009). Social Constructivism and European Integration. In A. Wiener \& T. Diez (Eds.), European Integration Theory (pp. 144-160). Oxford University Press.

Risse, T. (2010). A Community of Europeans? Transnational Identities and Public Spheres. Cornell University Press.

Scalise, G. (2015). The Narrative Construction of European Identity: Meanings of Europe 'from Below’. European Societies, 17 (4), 593-614.

Schmidt, V.A. (2011). The problems of identity and legitimacy in the European Union: Is more politics the answer?. In S. Lucarelli, F. Cerutti \& V.A. Schmidt (Eds.), Debating Political Identity and Legitimacy in the European Union (pp. 17-37). Routledge.

Standard Eurobarometer 85 European Citizenship (2016, Spring). Retrieved October 10, 2018, from http://ec.europa.eu/commfrontoffice/publicopinion/index.cfm/Survey/getSurveyDetai 1/instruments/STANDARD/

Standard Eurobarometer 89 European Citizenship. (2018, Spring). Retrieved March 29, 2019, from http://ec.europa.eu/COMMFrontOffice/PublicOpinion

Standard Eurobarometer 94. (2020-2021, Winter). Retrieved June 24, 2021, from https://europa.eu/eurobarometer/surveys/detail/2355

Treaty establishing the European Economic Community, 1957, https://www.cvce.eu/content/publication/1999/1/1/cca6ba28-0bf3-4ce6-8a766b0b3252696e/publishable_en.pdf

Weiler, JHH. (1998). To be a European Citizen - Eros and Civilization. Working Paper Series in European Studies, Special Edition, 1-52. 